\title{
On the creative economy chain in Brazil: potential and challenges*
}

\author{
Sobre a cadeia de cconomia criativa \\ no Brasil: potencial e desafios
}

\begin{abstract}
ANITA KON**
RESUMO: O artigo apresenta uma análise da Economia Criativa no Brasil, mostrando seu potencial de desenvolvimento para a geração de renda e emprego, visando à retomada do desenvolvimento no país. São apresentados inicialmente conceitos e características da Economia Criativa para em sequência analisar o perfil e as potencialidades de desenvolvimento desta indústria no Brasil. A parte empírica introduz aspectos metodológicos, prosseguindo com a análise da contribuição da cadeia criativa à geração de Valor Adicionado e de Trabalho do país, e uma visão do seu potencial no Comércio Exterior. Finalmente, são investigados os desafios para a implementação de políticas públicas específicas.
\end{abstract}

PALAVRAS-CHAVE: economia criativa; serviçoes; indústria, trabalho; desenvolvimento.

ABSTRACT: The article presents an analysis of the Creative Economy in Brazil, showing its development potential for the generation of income and employment, in order to the country's development resumption. They are initially presented concepts and features of the Creative Economy for, in sequence, to analyze the economic development profile and potential of this industry in Brazil. The empirical part introduces some methodological aspects, in continuing with the analysis of the creative chain contribution to the generation of Value Added and employment in the country, and a vision of their foreign trade.potential. Finally, the challenges to the implementation of public policies are investigated.

KEYWORDS: creative economy; services; industry; work; development.

JEL Classification: O; O2.

\footnotetext{
" The author thanks the support of the National Council for Research and Technological Development (CNPq).

** Professora da Pontifícia Universidade Católica de São Paulo (PUC), São Paulo, SP - Brasil. E-mail: anitakon@pucsp.br. Submetido: 18/Setembro/2014; Aprovado: 9/Outubro/2014.
} 


\section{INTRODUCTION}

The creative economy is increasingly becoming one of the relevant components of the modern post-industrial economies based on knowledge, due to the perception of its potential to generate income and employment, which is above the average of other sectors, but also because it is a cultural identity forger of some societies through the development process. Since the 1990s, some world governments have become aware of this fact and began to develop specific policies for the promotion of the creative economy, leading this economic sector, which previously presented only marginal interest, to a growing body of theoretical and empirical analyzes, in searching to find the relationships among knowledge, culture, creative industries and development, and to provide subsidies for public policy.

The creative industry has since been the focus of international discussions, under the stimulus of institutions such as the UNDP (United Nations Development Programme), UNESCO (United Nations Educational, Scientific and Cultural Organization) and UNCTADs (United Nations Conference on Trade and Development). This new approach is a strategic development axis for several countries in the twenty-first century, particularly after the international economic crisis, due to the fact that presents specific resource potential use, which are underutilized in some societies, to generate jobs and income, leading to new solutions for resumption of growth.

Given the nature of creative goods and services, which use the knowledge and intellectual capacity as an action base, the creative companies add these inputs to suit uncertainty and turbulence situations, by developing ideas that are often characterized by the condition that, once explored, lead to a series of new ideas, that are either developed internally to the production facility, either through a supply chain.

The Brazilian society is recognized for its cultural diversity and creative potential, however its creative economy figures in international research as performing a still in training planning strategy. Concern for the use of the Creative Economy potential in Brazil is very recent and has officially been focused as a measure to be implemented by public policies, since the creation of the Secretariat of the Creative Economy (SEC) in 2011, as an agency of the Ministry of Culture (MINC), with the mission of:

Lead the formulation, implementation and monitoring of public policies for local and regional development, giving priority to the promotion and support to professionals and to micro and small Brazilian creative endeavors. The objective is to contribute for this culture becomes a stra- 
tegic priority in public policy development of the Brazilian State. (Brazil, 2012, p. 39)

The first Creative Economy Management Plan by SEC, was launched for the 2011 to 2014 period, and in February 2012 it was established the Brazilian Observatory for Creative Economy (OBEC), as the entity responsible for the production and dissemination of research data and information on Brazilian creative economy, and also by stimulating debate. The SEC Plan seeks the implementation of transversal public policies directed to government sectors, the private sector and civil society, taking as a starting point, the building of a conceptual framework and guiding principles to support the institutionalization of a national policy which is geared to stimulating the creative chain in the country.

The crises in various fields experienced by the country, either social, economic, environmental and cultural, express the need to review and reform the development model so far applied. The exit from structural and economic problems of the Brazilian economy is a challenge to the inventiveness leading to the generation of economic surplus and to push for development resumption.

This article presents an analysis of the creative economy chain profile in Brazil, showing their development potential and the possibilities to use it for income generation and employment facing the stimulus for the country's growth recovery.

\section{CONCEPTS AND CHARACTERISTICS OF THE CREATIVE INDUSTRY}

Since the 2000s, the theoretical concept of "Creative Economy" internationally discussed as an economic development generator, functioning as driving developed and developing economies, as economies exchange jobs that are highly based in capabilities of operating engineering physical techniques production based on repetitive physical tasks, for jobs that require intellectual skills of analysis and judgment. The emergence of this new concept of Creative Economy was first used in the Australian Report 1994 "Creative Nation" and the notion of Creative Industries began to be discussed in 1997.

These concepts were later further developed in England and reflect the changes taking place in the global economy, where economies whose growth is centered on the production of goods, come to make room for growth driven by specific service sectors. These creative activities cover firms exploiting intellectual property which arise from creativity, as driving forces to generate wealth and jobs, causing effects in related industries and gaining influence as agents of their society political, social and educational changes. The broader term Creative Economy includes a wider range of activities that encompasses not only the cultural industries, but also

\footnotetext{
${ }^{1}$ Others terminologies are applied to this concept: Creative Industry, Experience Economy, Creativity Economy, Purple Economy, Meaning Economy, Creative Cities, Creativ Districts and Creaticity.
} 
all cultural, artistic and information production, produced by an individual unit. Thus, creative activities are those which the product or service contains a substantial element of creative content and also include activities such as architecture and advertising (Kon, 2014).

The diversity of these segments should not be understood only in the context of the product to be valued, but as a tangible economic asset or intangible key to a new understanding of development, which allows us to build alternatives and solutions for new ventures, for a new type of work and new forms of wealth production, also through the multiplier effect of value and labor creation that it is spread to the rest of the economy.

The UNO Report on Creative Economy shows that during the eruption of the 2008 global financial and economic crisis, there was a decrease in global demand and a $12 \%$ contraction of international trade. However, world exports of creative goods and services continued to grow at an average annual rate of $14 \%$ since 2002 . According to the publication, this is a confirmation that creative businesses have the potential for developing countries seeking to diversify their economies and seek more dynamic sectors to participate in the world economy (UN, 2010).

For UNCTAD, the creative economy is an evolving concept based on intangible assets that have the potential to generate economic growth and development, stimulate income generation, job creation and exports earnings, while promoting social inclusion, cultural diversity and human development. It encompasses cultural and social aspects that interact with technology, intellectual property and tourism objectives. It is a set of economic activities based on knowledge, with a dimension of development and interrelationships in micro and macroeconomic levels in the economy as a whole. It consists of a feasible development option, through innovation, with answers to the multidisciplinary public policy and ministerial action. At the heart of the creative economy are the creative industries (UNCTAD, 2011, p. xxiv).

Creativity can also be defined as the process by which ideas are generated, connected and transformed into things, tangible or intangible products that have value, that is, creativity is the use of ideas to produce new ideas. The UNO notes that the conceptual debate should not confuse creativity with innovation, because they are two different media, however innovation has an element of creativity, i.e., creation or renewal of something from nothing or from ideas. Nowadays the concept of innovation has been extended beyond the scientific and technological nature, involving aesthetic, artistic and other intangible changes (UN, 2010, p. 4).

The literature that presents these concepts shows that there are many definitions for the new phenomenon, that however are different ways of interpreting the same process, which are summarized in sequence. Who first developed the concept and the creative economy model was John Howkins (2001).

Thus, the most commonly cited definition of creative industry is published by the Department of Culture, Media and Sport (DCMS) of England:

those industries which have their origin in individual creativity, skill and talent and which have a potential for wealth and job creation 
through the generation and exploitation of intellectual property. (DCMS, 1998, p. 3)

The relevance of creative companies can be viewed by the ability of some types of intellectual capital to enable the creative talent of translation, information and other forms of communication, in effective production of new products and services or new forms of decision-making. Although the information and communication technologies have importance in all economic sectors, their use is dependent on the intensity of the intellectual capital of its operator. From this, these firms are often defined as producers and distributors of goods and services that are centered on texts, symbols, images or softwares, which are a specific group of activities based on knowledge, that usually combine creative talent with advanced technology, and whose product can be protected by property rights. The best examples of these activities are the visual and performing arts, such as music, film and television, video games, print and radio (Greffe, 2006).

A feature of the creative economy, particularly in developing countries, is the high prevalence of Informal systems, processes and cultural institutions. Informal creative industries, while generating considerable income share of the economy, are not adequately taken into account and their contribution to the added value generation is difficult to measure, undermining the government diagnosis for the creation of specific public policies.

The relevant potential of creative activities lies in the fact that they use as productive factors a number of elements that are not scarce in less developed or developing economies, and in some countries, natural resources. Creativity and traditional knowledge resources are found in these countries and the potential of these activities goes beyond income generation itself, to create creative chains that act as multipliers for other segments. With technological advancement the boundaries among creative industries and other industries tend to disappear. Thus, private and specific public policies aim to take advantage of the size of creating value chains of these creative products and, depending on the scale of production and the nature of the product, of the size of wider networks of values (Greffe, 2006).

To achieve these objectives, an essential component is the consideration of the importance of new communication and information technologies for the achievement of the idea that originates new forms of production, distribution and consumption of products, as well as new prospects for change in old concepts. One consequence of the creative industries is the possibility to transforming its condition of sectors that are relatively isolated from the rest of the world, to introduce them into the international trading system, which leads to the regulation of intellectual property and to the corporate control and responsibility.

One of the outstanding features of the creative industries, both in developed economies and developing countries, which tend to be centralized in towns or cities, is to present a considerable multiplier impact on the periphery of these centers, particularly in developing societies, where traditional ties of communities are weak, as well as the forms of more active social and economic participation. In this sense, they 
promote collective incentives for entrepreneurship in marginalized communities. However, often the economic potential of these new forms of production has still remained not achieved, given the lack of awareness of its potential, on the existence of intellectual property rights, the lack of access to global distributors and the ignorance of the benefits of other forms implementation of traditional production.

The creative economy is therefore the intangible economy, the symbolic, that feeds on creative talents, individually or collectively organized, to produce creative goods and services. Since this new vision of the economy has its own dynamic and multiplier effects, it requires to produce different from traditional economic models. His new business models are still under construction, lacking legal frameworks and appropriate conceptual basis which are adapted to the new world economic situation.

During the discussions on the operationalization of the creative economy ideas, several models have been proposed for the determination of the activities and components sectors of these industries, which are presented in summarized form in Chart 1 (see the next page).

One of the latest concept of creative economy is found in the publication of Bakhshi, Hardgreaves and Mateos-Garcia (2013, p. 13), "The Manifesto for the Creative Economy", which condenses the various ideas discussed: "Those sectors which specialise in the use of creative talent for commercial purposes ". Further defines the idea of creative occupation, as "a function in the creative process by making use of cognitive skills to bring a differentiation in the form of produce or innovate or to develop significantly improved products, whose final form is not fully specified in advance." In this manifest the signs of the model to be followed for prioritizing public policy emphasizes the "digital face of the creative industries" as the appropriate way to the reality of the United Kingdom, for which the document is directed.

So, it is observed that the differences between the productive structures and the conditions of the workforce in countries of different levels of development, committed to encouraging the creative economy, lead to concepts and to the choice of priority sectors that can better address the specific needs of each reality. In developing countries, where the issue to be resolved in order to generate employment and income in the short term is the inclusion of part of the workforce that has a lower level of qualification, priorities have been aimed at stimulating cultural and traditional sectors and activities better suited the capabilities of this population.

\section{THE CREATIVE CHAIN IN BRAZIL}

\section{Classification and measurement of activities}

The first "Management Plan of the Creative Economy" of the SEC establishes some cultural categories and sectors were selected by the Ministry of Culture as initial objects of encouraging public policies, such as: heritage (material, immaterial, archives and museums), cultural expressions (crafts, popular culture, visual 
Chart 1: Classification systems for creative industries in different models

\begin{tabular}{|c|c|c|}
\hline DCMS Model (1998) & Symbolic Texts Models (UN, 2010) & Concentric Circles Model (Throsby, 2007) \\
\hline $\begin{array}{l}\text { Advertising } \\
\text { Architecture } \\
\text { Art market and antiques } \\
\text { Handicraft } \\
\text { Design } \\
\text { Fashion } \\
\text { Film and Video } \\
\text { Music } \\
\text { Performing Arts } \\
\text { Publication } \\
\text { Software } \\
\text { Radio and TV } \\
\text { Video games and computers }\end{array}$ & $\begin{array}{l}\text { Core cultural industries } \\
\text { Advertising } \\
\text { Cinema } \\
\text { Internet } \\
\text { Publication } \\
\text { Radio and TV } \\
\text { Video games and computers } \\
\text { Peripheral cultural industries } \\
\text { Creative Arts } \\
\text { Border cultural industries } \\
\text { Consumer electronics } \\
\text { Fashion } \\
\text { Software } \\
\text { Sports }\end{array}$ & $\begin{array}{l}\text { Central creative arts } \\
\text { Literature } \\
\text { Music } \\
\text { Performing Arts } \\
\text { Visual arts } \\
\text { Other core cultural industries } \\
\text { Cinema } \\
\text { Museums and libraries } \\
\text { Broader cultural industries } \\
\text { Heritage Services } \\
\text { Publication } \\
\text { Sound recording } \\
\text { Radio and TV } \\
\text { Video games and computers } \\
\text { Related Industries } \\
\text { Advertising } \\
\text { Architecture } \\
\text { Design } \\
\text { Fashion }\end{array}$ \\
\hline Copyright WIPO Model (Greffe, 2006) & UNESCO Model (UNESCO, 2013) & American Model for Arts (CEC, 2013) \\
\hline $\begin{array}{l}\text { Core copyright industries } \\
\text { Advertising } \\
\text { Collective management societies } \\
\text { Film and video } \\
\text { Music } \\
\text { Performing Arts } \\
\text { Publication } \\
\text { Software } \\
\text { Radio and TV } \\
\text { Graphic arts and design }\end{array}$ & $\begin{array}{l}\text { Industries in core cultural domains } \\
\text { Museums, galleries, libraries } \\
\text { Performing Arts } \\
\text { Festivals } \\
\text { Visual arts and other } \\
\text { Drawing } \\
\text { Publication } \\
\text { Radio and Television } \\
\text { Film and video } \\
\text { Photography } \\
\text { Interactive media }\end{array}$ & $\begin{array}{l}\text { Advertising } \\
\text { Architecture } \\
\text { Services and art schools } \\
\text { Drawing } \\
\text { Movies } \\
\text { Museums and Zoos } \\
\text { Music } \\
\text { Performing Arts } \\
\text { Publication } \\
\text { Television and radio } \\
\text { Visual arts }\end{array}$ \\
\hline $\begin{array}{l}\text { Interdependent } \\
\text { copyright industries }\end{array}$ & $\begin{array}{l}\text { Industry in expanded cultural } \\
\text { domains }\end{array}$ & $\begin{array}{l}\text { Canadian } \\
\text { model (CBC, 2008) }\end{array}$ \\
\hline $\begin{array}{l}\text { Recording Materials } \\
\text { Consumer electronics } \\
\text { Musical Instruments } \\
\text { Paper } \\
\text { Photocopying and photography } \\
\text { Industries of partial copyrights } \\
\text { Achitecture } \\
\text { Clothing and footwear } \\
\text { Graphic design } \\
\text { Fashion } \\
\text { Decoration } \\
\text { Toys }\end{array}$ & $\begin{array}{l}\text { Musical Instruments } \\
\text { Sound Equipment } \\
\text { Architecture } \\
\text { advertising } \\
\text { Printing Equipment } \\
\text { Software } \\
\text { Audiovisual hardware }\end{array}$ & $\begin{array}{l}\text { Written media } \\
\text { Film industry } \\
\text { Broadcasting } \\
\text { Sound Recording } \\
\text { Publishers of music } \\
\text { Performing Arts } \\
\text { Visual arts and other } \\
\text { Architecture } \\
\text { Photography } \\
\text { Graphic design } \\
\text { Advertising } \\
\text { Museums and art galleries } \\
\text { Files } \\
\text { Libraries } \\
\text { Cultural education }\end{array}$ \\
\hline
\end{tabular}

Source: UM (2010, P.7). UNCTAD (2010, p. 22). Author's, elaboration. 
and digital arts), performing arts, audiovisual, publications and print media, and cultural and functional creations (fashion, design, architecture) (Brazil, 2012, p. 30).

However, the creative industries are not limited to these selected cultural sectors, but also include software sectors, computer \& telecommunication, research $\&$ development and biotechnology, as relevant to the creation of income and employment from intangible elements intrinsic to its activities.

The measurement of this chain in Brazil is still limited and scarce since the production of more specific statistical data is in the conceptual stage of discussions and the few existing studies have not yet defined a methodology that would match the diverse views. There is no specific satellite account in the IBGE National Accounts surveys to measure the activities and products of the creative sectors. It has not yet been defined in the country a guideline for public bodies related to the standardization of classification and framing of these economic activities and creative workforce.

Given the recognition by some experts that culture also generates a not inconsiderable amount of income, employment and export revenue, one of the first estimates of measurement of the Brazilian creative economy was made in 2004 when the Ministry of Culture asked for a national mapping to identify the size of the cultural sector in the country. The survey collected information from more than 320,000 cultural businesses, concluding that cultural industries accounted for 1.6 million jobs, $5.7 \%$ of total business and $4 \%$ of the 2003-2005. country's labor However, this research has suffered from the lack of national indicators on supply, demand and access to cultural products and services, which was a limitation to the formulation of cultural policies (UNCTAD, 2014).

Some business institutions such as the Rio de Janeiro Federation of Industries (FIRJAN), or specific governmental as the Administrative Development Foundation (FUNDAP), made specific empirical studies based on data from the Annual Social Information (RAIS), only on formal enterprises, about the amount of creative enterprises considered according to the IBGE's National Classification of Economic Activities (CNAE 2.0) IBGE and information of United Nations Conference on Trade and Development (UNCTAD/UN, 2012).

More recent FIRJAN studies have focused wider empirical research whose results were first published in 2008 and has been updated to set the Brazilian creative Industry chain and to estimate its economic relevance. This chain was defined by three levels, namely: i) Core, composed of 12 leading sectors, whose main input is creativity; ii) Related Activities involving direct provision segments of goods and services to the Core, largely made up of industries and service companies supplying materials and key elements for its operation; and iii) Support Activities, which includes suppliers of goods and services more indirectly.

Empirical analysis carried out in this article, based on the Service Annual Research (PAS/IBGE), were prepared by selecting data to represent the intangible specific activities of the creative economy, according to the concepts defined by the aforementioned institutions, as the possibility of breakdown of the information from the CNAE 2.0, as shown in Chart 2. 
Chart 2: Categories and selected sectors of the creative chain in Brazil

\begin{tabular}{|c|c|}
\hline Categories & Sectors - CNAE 2.0 \\
\hline $\begin{array}{l}\text { Cultural, recreational and sports } \\
\text { activities. }\end{array}$ & $\begin{array}{l}90 \text { - Artistic, creative and spectacles activities } \\
90 \text { - Performing Arts, shows and complementary activities } \\
\text { and artistic creation } \\
93 \text { - Sports facilities management and sports activities not } \\
\text { otherwise specified } \\
96 \text { - Other cultural and sporting activities }\end{array}$ \\
\hline Telecommunications & $\begin{array}{l}60-\text { Radio and television activities } \\
61 \text { - Telecommunications }\end{array}$ \\
\hline Information Technology & 62 - Activities of services information technology \\
\hline Audiovisual services & $\begin{array}{l}59 \text { - Cinematographic activities, videos and television pro } \\
\text { grams production } \\
74.20 \text { Photographic and similar activities } 74.20-0\end{array}$ \\
\hline $\begin{array}{l}\text { Editing and other integrated } \\
\text { to printing }\end{array}$ & 58 Edition and integrated to printing editing \\
\hline $\begin{array}{l}\text { News agencies and other } \\
\text { information services }\end{array}$ & 63 - Activities of information services provision \\
\hline Architecture and Design & $\begin{array}{l}71.1 \text { - Architecture or engineering services } \\
74.10 \text { Design and interior decoration }\end{array}$ \\
\hline Advertising & 73.1 Advertising agencies \\
\hline
\end{tabular}

Source: IBGE/PAS (2010). Author's elaboration.

It must be noted that the information for a series of tangible creative products are not available in a form that would be consistent with the analysis of intangible products. Considering that have not very significant participation in the context of the creative chain, creative goods are separately considered, only in the foreign trade analysis, however are considered in the aggregate data on the overall chain.

\section{The contribution of the creative chain to the added value generation}

The contribution of the Core (leading sectors) of the creative chain to the generation of added value corresponded in 2011 to a percentage between 1\% and $6 \%$ in world countries. The UK's which longest promotes the study and the implementation of public policies that specifically address these sectors of the economy, recorded in 2014 a higher share than $6 \%$ in the contribution to GDP, although in absolute monetary terms the United States generates a value of 3.5 times higher. In this context, Brazilian data $(2.7 \%$ of GDP) place the country in a good situation as comparing with the global creative economy.

UNCTAD's aggregate information (2011) converted into Reais by FIRJAN (2011) show that the GDP generated by Brazilian creative core firms (R $\$ 110$ billion), that although is low compared to the GDP volume, is significant and has 
exceeds that of countries like Italy, Spain and the Netherlands. In the country, although the data show an alignment to this international trend and in 2011 this Core was made up of 243,000 firms, it is still not full explored the development potential of these sectors.

According to the "System of Information and Cultural Indicators" (IBGE/ Ministry of Culture, 2006), the Brazilian creative sector accounted in 2003 for $5.7 \%$ of formal jobs, $6.2 \%$ of the number of companies, $6 \%$ of value added and $4.4 \%$ of the average expenditures of Brazilian families. Creative companies accounted for $5 \%$ of industry jobs in the country, with an average salary of 5.6 minimum (comparing to 4.6 of the entire industry). With respect to services, the data are even more significant: $9 \%$ of total employment and 5.9 minimum average salary (to 3.2 for all services).

One of the relevant considerations on the Core of the creative economy as a central point of analysis is the condition of being the center that drives the advancement of value creation of a chain, as seen. The observation data of the entire chain of the Brazilian creative economy, which includes Related and Support activities, shows a set of more than two million businesses. FIRJAN estimates (2008) based on payrolls generated by these formal enterprises find that the value of creative GDP of the entire chain amounted to R \$ 735 billion, which in 2010 was $18.2 \%$ of the Brazilian GDP, highlighting that this comparison does not incorporate the informality in the Brazilian economy. As seen in Figure 1, the multiplier effect of product generation by the Core activities is very large and has the potential to stimulate employment and income creation and wider economic development of the economy.

Figure 1: Distribution of the creative chain GDP in groups of activities, Brazil, 2006

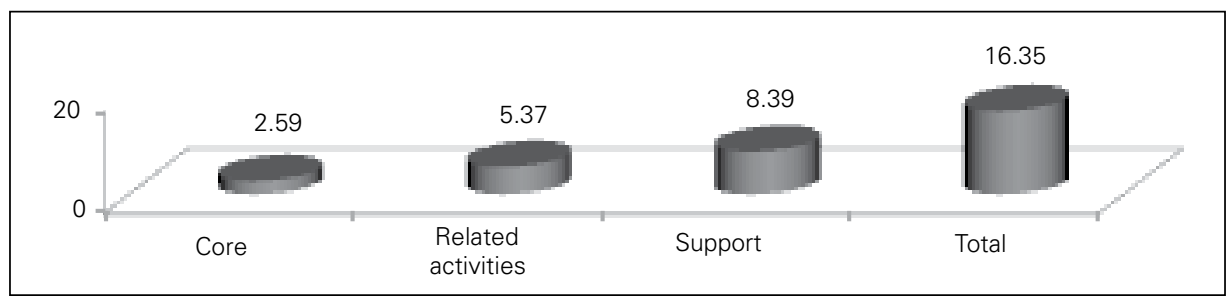

Source: FIRJAN (2008). Author's elaboration.

The regional analysis shows that in Brazil the most advanced states of São Paulo and Rio de Janeiro the Core creative representation in GDP exceeds 3.5\%. However, research indicate that despite the coverage of its production chain the creative economy in Brazil is not among the top 20 in the world, led by China, the United States and Germany, and is below its potential (UNCTAD, 2010).

The annual growth of the creative sector in the years 2006-2010 was not low $(6.13 \%$ pa) being greater than the annual GDP growth $(4.3 \%)$, suggesting the need for better use of its possibilities, since there is a trend in this sector to gain greater economic relevance in the GDP generation (FIRJAN 2012 p. 30). The measurement 
of real value added (VA) growth rates generated by creative firms from the IBGE's PAS research, as to some categories previously defined in Figure 2, show different dynamics from 2008 to 2010, as seen in Figure 2. Note that the intensity of dynamism growth of these activities are not regular in the period, since in 2008 the most dynamic related to Edition and similar activities $(19.2 \%)$ and of News agencies and other types of information $(29.2 \%)$, registered well superior rates as to the others in this year, when it could be already felt the first effects of the global financial economic crisis that came with more intensity in the country from 2008 September on.

Figure 2: Annual growth rate of real gross value added of selected

Brazilian creative activities. 2008, 2009 and 2010 (\%)

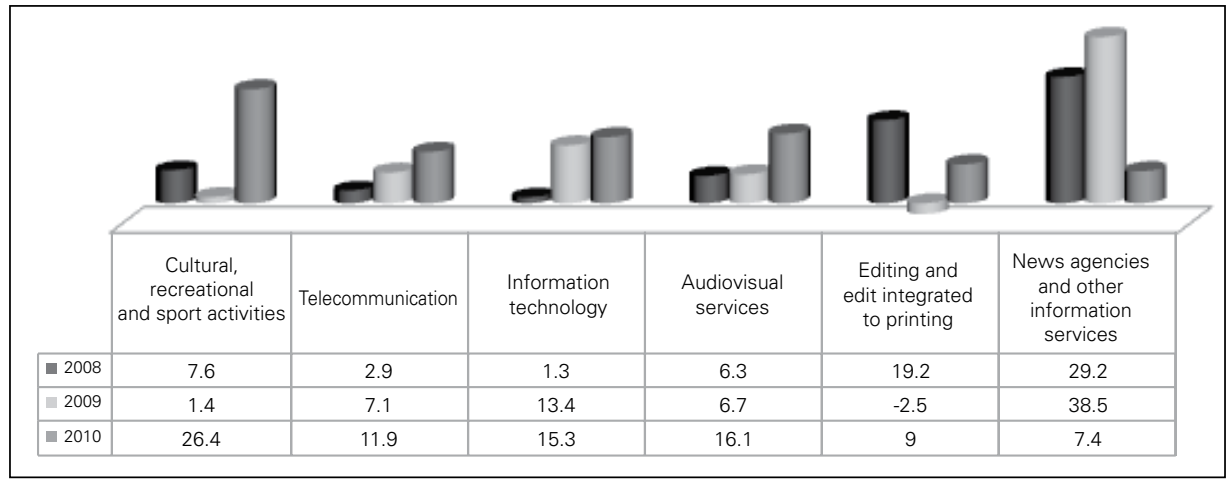

Source: IBGE/PAS (2010). Author's elaboration.

The 2008 financial crisis had different impacts on the Brazilian creative economy, as shown in Figure 2, and in 2009 some of these activities resented more strongly of the world situation and the VA growth rates decreased, in such as Cultural, recreational and sports activities $(14 \%)$ and activities related to Edition $(-2.5 \%)$, while the other groups increased growth rates, some very substantially, as Telecommunications (from $2.9 \%$ to $7.1 \%$ ), Information Technology (of $1.3 \%$ to $13.4 \%$ ) and News agencies and other types of information $(29.2 \%$ to $38.5 \%)$. The dynamic behavior of these latter activities contrasts considerably from the overall GDP growth behavior of the Brazilian and world economy in this year, which had negative rates of $-0.3 \%$ and $-2.3 \%$ respectively, while emerging economies grew $2.5 \%$.

In 2010, the global recovery has already begun with the return of global economic growth (4\%) and also in Brazil (7.5\%) (FUNDAP, 2012). This Brazilian reaction, whose high rates reflect the recovery from the low base level of 2009 GDP, also has significantly reflected in the VA growth of creative activities with greater intensity in the group of Cultural, Recreational and Sports activities (26,4\%), which shows the potential of these modalities, which are a set of activities that have lower capital-labor ratio, highly characteristic of the Brazilian economy. However, sectors that have recorded higher capital-labor relationship as Telecommunications, Information Technology and Audiovisual Services also showed considerable growth rates, driven by increased capacity utilization and strong increase in gross fixed 
capital formation $(28.5 \%)$ in the first half of 2010 together with the resumption of credit operations to individuals, which has driven the growth of these creative units.

\section{Creative Economy and Labor}

The first FIRJAN (2010) study on the creative activities, showed that 12 of the Core sectors in 2006, together with the creative chain Related and Support activities accounted for $21.8 \%$ ( 7.6 million people) of the country's total formal employment (35 million), contributing to $16.2 \%$ of GDP. Regarding the number of workers in the activities of the Core of the creative industry, the workers in Brazil increased from 599,000 to 771,000 between 2006 and 2010. The number of "creative" employees grew on average $8.5 \%$ per year during this period, which accumulates $29 \%$ in four years; this rate was more accelerated than the Brazilian general labor market $(5.8 \%$ per year or $25 \%$ in the period). Thus, employees in the creative Core in 2010 represented $1.75 \%$ of all Brazilian workers, compared to $1.70 \%$ in 2006.

The Manufacturing Industry, supplier of raw materials and finished goods to the creative Core, employed $67 \%$ of workers in Related Activities. In turn, the core activities accounted for $32.5 \%$ of the establishments of an universe of 2.8 million. These data allow us to identify the significant representation of the production chain in the Brazilian economy, with regard to workers and other professionals absorption capacity.

The distribution of employees in the core activities from IBGE's PAS and PNAD data for the period 2007-2010 (Table 1) show that more than 887,000 formal workers in 2007 , which represented $1 \%$ of the total employed population and $2.9 \%$ of formal workers, the number of workers has evolved into more than 1.062 million, corresponding to $1.96 \%$ and $3.1 \%$ respectively of the employed population in the country and of the employed population with a formal. Estimates for 2010 show that considering all the creative chain, people who held formal jobs accounted for $8.54 \%$ of formal employment in Brazil.

The most representative of the Core sectors are Information Technology activities (more than 1/3 of workers), Telecommunications (around 15\%) and those related to Edition, whose rates of annual change in the period, however were not the greatest (Figure 3). In 2007, Cultural, recreational and sports activities as well as News agencies and information services, had an amazing growth above $20 \%$, as well as the Telecommunications $(13 \%)$, but those relating to the Edition show a decrease in number of workers.

It is interesting to note that in the 2009 crisis year, when there was a considerable decrease in the Brazilian productive activity, the development of formally employed in the creative core continued to show positive rates and particularly the sectors linked to News agencies considerably increased the number of workers, due the need for comprehensive information on overwhelming situation. The beginning of economic recovery in 2010 shows a positive and significant impact on the uptake of formal workers in these sectors. 
The number of formal enterprises in the 2007- 2010 period increased only in the sectors of Cultural, recreational and sports activities and those linked to news, and for most of the sectors, the ratio of workers by enterprises decreased or remained stagnant, with the exception of the sectors that are more labor intensive such as Architecture and Engineering services, which have a considerably higher ratio compared to other, and Advertising (Table 1).

Table 1: Distribution of Workers and enterprises in the

Core activities of the creative chain in Brazil, 2007, 2009 and 2010

\begin{tabular}{|c|c|c|c|c|c|c|c|c|c|}
\hline \multirow{2}{*}{ Categories } & \multicolumn{3}{|c|}{ Workers (\%) } & \multicolumn{3}{|c|}{ Enterprises (\%) } & \multicolumn{3}{|c|}{ Workers/Firms } \\
\hline & 2007 & 2009 & 2010 & 2007 & 2009 & 2010 & 2007 & 2009 & 2010 \\
\hline $\begin{array}{l}\text { Cultural, recreational } \\
\text { and sport activities }\end{array}$ & 9.8 & 11.5 & 11.9 & 20.1 & 23.2 & 23.2 & 5 & 5 & 5 \\
\hline Telecomnunication & 13.6 & 14.9 & 15.0 & 3.7 & 3.4 & 3.4 & 37 & 46 & 44 \\
\hline $\begin{array}{l}\text { Information } \\
\text { Technology }\end{array}$ & 39.1 & 37.6 & 36.7 & 52.1 & 48.7 & 48.7 & 8 & 8 & 7 \\
\hline Audiovisual ervices & 11.4 & 11.5 & 11.1 & 9.7 & 10.3 & 10.3 & 12 & 12 & 11 \\
\hline $\begin{array}{l}\text { Editing and edit } \\
\text { integrated to printing }\end{array}$ & 12.8 & 12.0 & 11.7 & 11.8 & 11.3 & 11.3 & 11 & 12 & 10 \\
\hline $\begin{array}{l}\text { News agencies and } \\
\text { other information } \\
\text { services }\end{array}$ & 0.5 & 0.8 & 0.9 & 1.0 & 1.9 & 1.9 & 5 & 5 & 5 \\
\hline $\begin{array}{l}\text { Architecture and } \\
\text { engineering }\end{array}$ & 8.7 & 10.0 & 11.0 & 1.0 & 0.9 & 0.9 & 89 & 108 & 116 \\
\hline Advertising & 4.1 & 1.7 & 1.7 & 0.7 & 0.3 & 0.3 & 57 & 56 & 58 \\
\hline TOTAL & 100.0 & 100.0 & 100.0 & 100.0 & 100.0 & 100.0 & 10 & 10 & 10 \\
\hline $\begin{array}{l}\text { Total Valores } \\
\text { Absolutos }\end{array}$ & 887,534 & 963,033 & $1,062,153$ & 88,658 & 94,648 & 108,187 & - & - & - \\
\hline II/TOP (\%)* & 1.0 & 1.6 & 2.0 & - & - & - & - & - & - \\
\hline $\mathrm{Cl} / \mathrm{FW}(\%)^{* *}$ & 2.9 & 2.8 & 3.1 & - & - & - & - & - & - \\
\hline
\end{tabular}

Souces:IBGE/PAS (2007, 2009 e 2010) and IBGE/PNAD (2007, 2009 e 2011). Author's elaboration.

${ }^{*} \mathrm{Cl}=$ Creative Industry; TOP $=$ Total occupied population. ${ }^{*} \mathrm{FW}=$ Formal Workers 


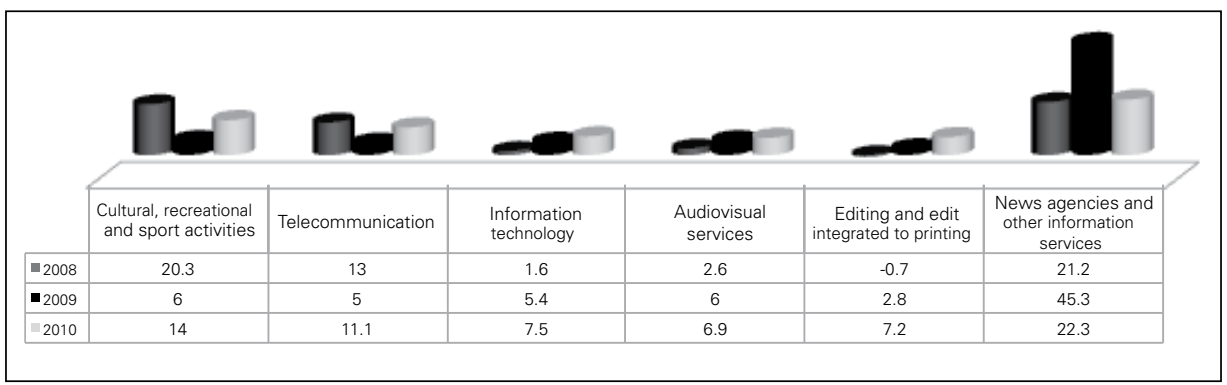

Source: IBGE/PAS (2010). Author's elaboration.

Note that the characteristic of creative activities in Brazil is related to the very high participation of workers in informal activities. as self-employed or workers in companies without a formal contract. With regard to informal work, FUNDAP (2010), made some estimates based on the National Survey of Households (PNAD) informations, noting that in Brazil, the number of formal and informal jobs in creative activities between 2006 and 2009 increased from 87.2 million to 91.6 million, an increase of $5 \%$ in 2009 and corresponds to about $3.5 \%$ of the total formal and informal labor in the country, $4.7 \%$ in the Southeast and $5.2 \%$ in São Paulo.

Figure 4: Number of formal and informal workers in the creative chain Core, Brazil, 2007-2010

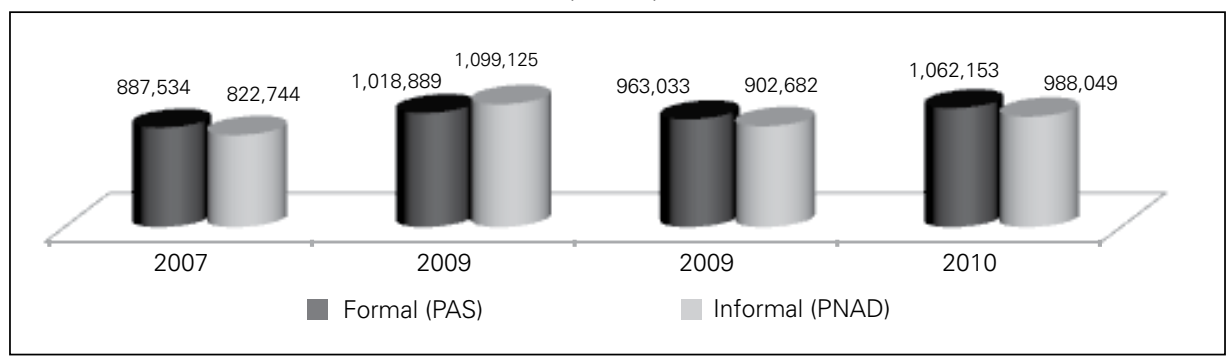

Sources of raw data: IBGE/PAS (2007, 2009 e 2010) and IBGE/PNAD (2007,2009 e 2010). Author's elaboration.

Figure 4 first shows that the representation of informal workers is close to the formal and above it only in 2008, when the economy was still expanding before September, and in a year in which the formal and informal workers Core amounted to approximately 2.1 million. In 2009, the number of workers in the Core decreased to nearly 1.9 million, but rises in the subsequent recovery year, when formally employed increased relatively more. The activities carried out informally, do not include a focused strategic management for results, with lower qualification levels of most workers, and prevents better results in terms of added value generated and average wages. 

of creative industries, Brazil, 2007-2010 (\%)

\begin{tabular}{|c|c|c|c|c|c|c|}
\hline & $\begin{array}{c}\text { Cultural, } \\
\text { recreational } \\
\text { and sport activities }\end{array}$ & Telecommunication & $\begin{array}{l}\text { Information } \\
\text { technology }\end{array}$ & $\begin{array}{c}\text { Audiovisual } \\
\text { services }\end{array}$ & $\begin{array}{l}\text { Editing and } \\
\text { edit integrated } \\
\text { to printing }\end{array}$ & $\begin{array}{l}\text { News agencies } \\
\text { and other } \\
\text { information } \\
\text { services }\end{array}$ \\
\hline - 2007 & 32.6 & 11.4 & 40.3 & 31.1 & 43.5 & 41.0 \\
\hline 2008 & 32.6 & 11.8 & 42.9 & 32.0 & 38.5 & 39.2 \\
\hline$=2009$ & 37.8 & 11.0 & 44.5 & 35.6 & 38.1 & 36.2 \\
\hline 2010 & 32.1 & 11.0 & 46.7 & 31.6 & 38.4 & 40.6 \\
\hline
\end{tabular}

Source: IBGE/PAS (2010). Author's elaboration.

An IPEA study shows that when compared the formal sector with total market, it is observed that wages in the formal sector tend to be larger. On the other hand, total labor market workers of creative economy tend to earn more than the global economy average, so that the participation of the creative economy in wages is higher than the participation in employment (IPEA, 2013).

The share of wages of formal workers in the creative Core sectors corresponds to around $40 \%$ in activities related to Information Technology, Publishing and News, however only the first category this representation increased from 2007 to 2010. In the Cultural, recreational and Audiovisual activities wages account for about $1 / 3$ of the VA generated, and as it is observed that in Telecommunications, a labor-intensive sector, these gains participate with only $11 \%$ (Figure 5). However, in recent creative activities the evolution of average monthly wages was higher than the others in the period, although the rates have decreased from over $8 \%$ in 2007 to $6 \%$ in 2010. Among the other activities, only the group of Cultural ones showed lower rates around $1.5 \%$, while the other categories had a wage increase of around $4 \%$ to $5 \%$ (Figure 6 ).

Figure 6: Evolution of the average monthly wage in the creative industries, Brazil, 2007-2010 (in minimum wages)

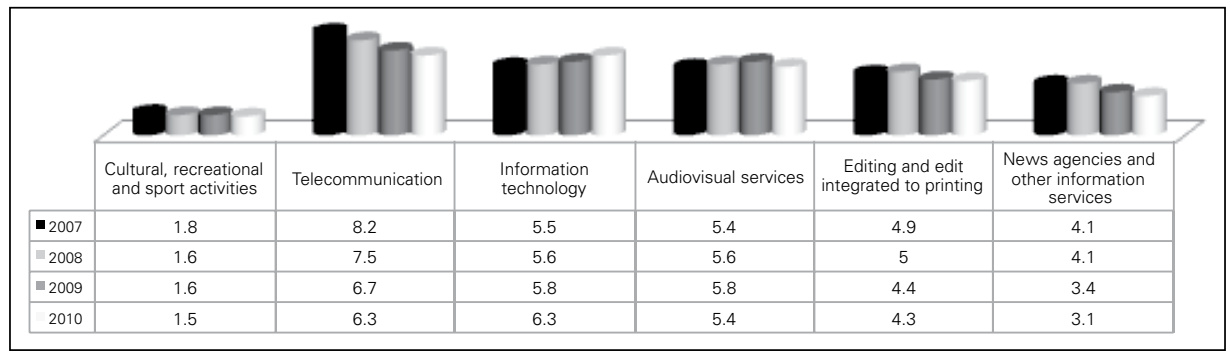

Source of raw data: IBGE/PAS (2010). Author's elaboration. 
The observation of the average income of Brazilian workers in the formal Core of creative industry shows that this earning increased from R \$1,663 in 2006 to $\mathrm{R} \$ 2,296$ in 2010 , equivalent to a real growth of $13 \%$ in the period, value which is $45 \%$ higher than the formal employees average ( $\mathrm{R} \$ 1,588)$, while the average income of total Brazilian workers grew by $11 \%$ in this period. The 2011 survey update shows that while the average monthly income of Brazilian workers was R\$ 1,733 , the creative sectors one reached $\mathrm{R} \$ 4,693$, almost three times the national level (FIRJAN, 2012).

Figure 7: Average earnings in the creative Core according to categories, Brazil, 2011

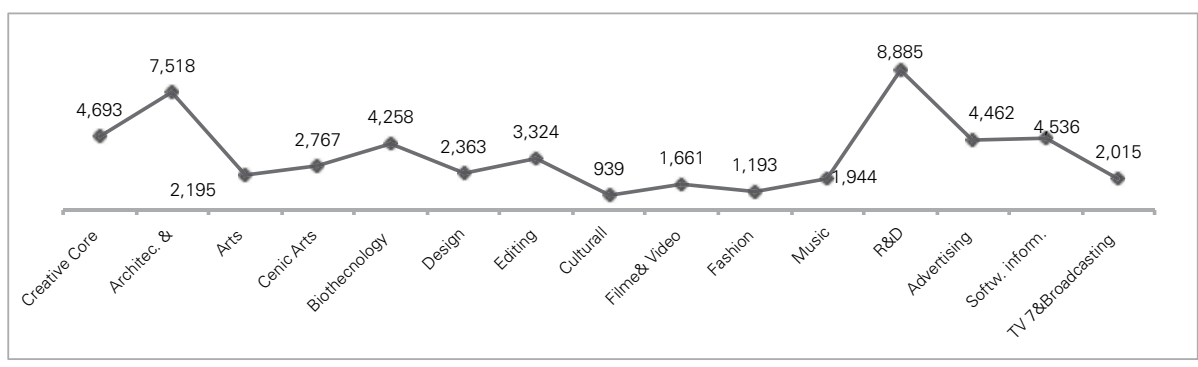

Source: FIRJAN (2012). Author's elaboration.

As shown in Figure 7, the $\mathrm{R} \& \mathrm{D}$ segment is the one with the highest average wage ( $\mathrm{R} \$ 8,885)$ which is $89 \%$ above the average remuneration of the creative Core, due to the highly skilled technique of these workers and among them, geologists and geophysicists have the biggest gains, with an average yield of $R \$ 11,385$, nearly seven times the national average.

The Architecture \& Engineering segment is the one with the greatest impact, concentrating more than a quarter of this universe and these activities have average earnings $(\mathrm{R} \$ 7,518)$ considerably higher $(60 \%)$ than the Core ones. In sequence, the segments of Software and Computing, as well as Advertising and Design (the latter employ more than 100,000 workers), present a remuneration corresponding to the Core average. Together, these three groups concentrate half of Brazilian workers and creative professionals require a high degree of training, contributing to generation of higher value added products.

Note that the categories of Cultural Expressions and Fashion, have lower average earnings, which are $75 \%$ to $80 \%$ below the global average and the latter group accounts for almost $30 \%$ of the establishments $(620,000)$ of the creative industry chain in the country, below the Architecture \& Engineering segment. The services related to Fashion in 2006 recorded earnings $80 \%$ above the average and the considerable decrease in the 2011 average was due to the fact that a significant increase in activities and workers in this segment was due to the expansion of smaller companies that produce more popular articles in remote regions of the economic centers. On the other hand, the number of jobs generated by the Fashion chain is considerable, reaching 1.2 million people since it mobilizes from fashion 
designers to sellers that provide the final product to the a wider range of people, which shows the potential of job creation and added value that these activities have, if better stimulated.

Considering the global creative chain of the Brazilian economy, the analysis shows that were included in these activities more than 11 million workers who together accounted for $24 \%$ of formal workers in the country. The composition according to macro sectors reveals that over $47 \%$ of workers of these activities are focused on manufacturing and other industries, while other workers were distributed through Commerce and Services, which grouped respectively $27.6 \%$ and $25.2 \%$ of employed in 2010 (FIRJAN, 2012).

\section{FOREIGN TRADE OF CREATIVE INDUSTRY}

Nowadays, the creative economy has proven to be one of the fastest growing segments of the exports in the world economy and highly transformative, in terms of income generation, job creation and earnings. The market growth for these activities goods and services was also seen in the foreign trade of the countries and, as shown in UNCTAD (2013), the value of annual exports of this segment increased from US\$ 227 billion to US\$ 624 billion from 1996 to 2011, a result that doubled 2002 , despite some periods of global financial crisis after 2008. While international trade fell $12 \%$ in 2008 , exports of creative goods and services grew by $14 \%$ and doubled in volume 6 years. In the 2007-2010 global financial crisis period, although less intense growth rates, they still were positive and particularly significant for some categories in some developing countries. This behavior shows the potential resilience of these services in times of crisis as well as the ability to continue to support income generation in critical periods of the economy (Kon, 2014).

In Brazil, exports of creative goods and services recorded sales of US\$ 7,533 million in 2008, according to UNCTAD, of which $16.2 \%$ (US\$ 1,222 million) were related to goods and $83.8 \%$ (US \$ 6,331 million) were of intangible services. While these sales are only about $3.7 \%$ of the total value of these activities (US\$ 592 billion) exported by the rest of the world, there is great room and potential for expansion of the creative exports (SEC, 2011). In the world scenario, exports of creative goods are more representative than services, and on the contrary to Brazil, recorded that year $68.6 \%$.

Within the overall context of Brazilian foreign trade, from 2006 on, the floating exchange rate without a control policy, began to hinder the development of exports and stimulate imports. With greater appreciation of the real from this year to 2011, the trade balance that had been showing strong growth in previous years rendered to more difficult export conditions especially for manufactured goods, which is confirmed until 2011. In this global foreign trade scenario in Brazil, creative products began to develop a specific market for exports, since imports of these goods and services had already occurred previously.

The monetary volume of Brazilian exports and imports of creative services and 
goods for the period 2003 to 2012 (Table 2), initially shows that the volume of intangible activities sales abroad is higher than that of foreign purchases, and this Balance surplus is due particularly to the type of architecture, engineering and other related intangible technicians services, whose share in Brazilian foreign trade is around $88 \%$. The Services Balance for the global country, has been constantly in deficit from 2006 on, and thus creative activities follow a proper dynamics in the foreign trade, and the domestic production is more representative and less dependent on the outside, although growth has been limited by weak incentives to technological progress.

Table 2: Value of exports and imports of services and creative goods in Brazil. 2003 and 2012

\begin{tabular}{l|cc|cc}
\hline & \multicolumn{2}{|c|}{ Exports } & \multicolumn{3}{c}{ Imports } \\
\cline { 2 - 5 } & 2003 & 2012 & 2003 & 2012 \\
\hline Creative services & 1.719 & 10.309 & 1.771 & 7.725 \\
Advertising, market research, opinion polls & 102 & 701 & 62 & 921 \\
Architecture, engineering and other technical services & 1.509 & 8.945 & 1.036 & 4.704 \\
Research and development & $\ldots$ & 577 & $\ldots$ & 42 \\
Personal, cultural and recreational services & 54 & 43 & 337 & 1.034 \\
Audiovisual and other related & 29 & 13 & 250 & 965 \\
Other Personal, cultural and recreational & 25 & 30 & 86 & 69 \\
\hline Ceative goods & 71 & 310 & 244 & 1851 \\
Toys & 18 & 13 & 33 & 411 \\
New media & 1 & 111 & 5 & 375 \\
Recorded media & 1 & 94 & 2 & 294 \\
Video games & 1 & 0 & 2 & 81 \\
Musical Instruments & 4 & 2 & 14 & 127 \\
Musical scores & $0 *$ & $0 *$ & $0 *$ & $0 *$ \\
Publications & 36 & 35 & 179 & 479 \\
Fine Art & 10 & 55 & 9 & 84 \\
\hline
\end{tabular}

Sorce: UNCTADstat (2014). ${ }^{*}=$ less than US\$ 1 milhão. Author's elaboration.

The growth in the creative services trade is almost always positive in the period, both for sales and for purchases abroad, in all forms, highlighting the export of services related to IT and royalties, with average annual rates of respectively $27.6 \%$ and above $25 \%$ (Table 3). However, in the period increased sales of other Business services, Advertising and Architecture and engineering services were relatively very large (over 20\%). Despite the repercussions of the international financial crisis from 2007 to 2011, which resulted in decreasing of exports in some types of Personal creative services, Cultural and recreational as well as some related to Information, nevertheless other categories of exported creative services continued 
with significant sales growth. In turn, purchases of these services from abroad also registered an increase at very considerable rates, particularly in Advertising categories, Market research, opinion polling, who reached annual rates above $32 \%$. Brazilian imports during the crisis remained high due to domestic demand, with the exception of 2009, when total Brazilian exports had a decrease of $26 \%$.

In turn, the Brazilian creative goods trade shows to be less relevant than services ones and the balance is always in deficit. The monetary volume of imports exceeds by nearly six times the sales of these goods to other countries in the years 2008 and 2012 (UNCTAD, 2014). The most relevant participation among the modalities of goods after 2008 is seen for the Recorded media and Other new media, which together account for $66 \%$ of exports (US\$ 205 million) and $36 \%$ for purchases (US\$ 669 million) in 2012. On the imports side, it also stand out Publications $(26 \%)$ and Toys $(22 \%)$. The other categories although with a less relevant participation, show the potential market niches whose production could be stimulated to boost exports, or replace some imports given internally to demand.

Table 3: Exports and imports annual average rate growth of creative goods and services, Brazil. 2002-2001 and 2007-2011

\begin{tabular}{|c|c|c|c|c|}
\hline & \multicolumn{2}{|c|}{ Exports } & \multicolumn{2}{|c|}{ Imports } \\
\hline & $\begin{array}{c}2002 / \\
2011\end{array}$ & $2007 / 2011$ & $2002 / 2011$ & $2007 / 2011$ \\
\hline \multicolumn{5}{|l|}{ Creative services } \\
\hline Computing and IT & 27,6 & 9,1 & 16,4 & 14,8 \\
\hline Royalties & 25,2 & 11,3 & 13,4 & 8,5 \\
\hline Other business services & 20,5 & 13,3 & 24,8 & 24,4 \\
\hline Advertising, market research, opinion polls & 22,3 & 26,7 & 32,1 & 42,2 \\
\hline Research and development & $\ldots$ & 23,9 & $\ldots$ & 28,6 \\
\hline Architecture, engineering and other technical & 20,3 & 11,8 & 20,5 & 16,5 \\
\hline Personal services, cultural and recreational & 5,1 & $-3,9$ & 18 & 15,8 \\
\hline Other Personal, cultural and recreational & 9,1 & $-4,3$ & 8,6 & $-15,8$ \\
\hline Information Services & 12,1 & $-0,2$ & 8 & 9,7 \\
\hline \multicolumn{5}{|l|}{ Creative goods } \\
\hline Toys & $-4,13$ & -7 & 30,43 & 12,74 \\
\hline New media & 85,7 & 90,2 & 20,7 & 15,4 \\
\hline Recorded media & 122,5 & 103,7 & 22,6 & 10,38 \\
\hline Video & 2,53 & $-37,6$ & 59,4 & 60,5 \\
\hline Musical Instruments & $-9,34$ & 29,5 & $-22,4$ & 19,7 \\
\hline Musical scores & 24,1 & 55,9 & $-3,93$ & 53,9 \\
\hline Publications & $-3,5$ & 10,6 & $-4,7$ & 2,18 \\
\hline Fine Arts & 22,3 & 26,1 & 20,25 & 23,4 \\
\hline
\end{tabular}

Source: UNCTADstat (2014). Author's elaboration. 
In turn, the dynamics of this trade has been increasing, although some categories exports of goods such as Toys, Publications and Musical instruments have lost ground in the period; the two latter presented negative sales results from 2003 to 2007 , but in the next period have shown positive growth rates (Table 3). Video game sales, which grew throughout the first analyzed period, showed a significant decrease in growth rates after 2008, which suggests that there is a market that can potentially be recovered.

The sales abroad of New and Recorded media in the period took a very fast pace, particularly for the latter, whose results were greater than $100 \%$ per year and show the market recovery from a previous period with negative rates. It should be noted particularly that the Musical scores, although presenting some significant sales figures in the general context, had a tendency of very high growth from 2008 .

In what refers to imports, the decrease rates recorded in purchases of Musical instruments for the whole period, showed the same trend as the exports of creative products, because from 2003 to 2008 there was a decrease in these flows as a result of the existing exchange rate policy and the emergence of more competitive foreign industries than Brazilian ones, in the international market. But from 2008 to 2012, there was considerable evolution of import duties and the relevance of creative goods flows is shown by the potential multiplier effect for the creative industry, since these are productive musical and othr cultural activities chain links. This growth was linked to the advancement of cultural developments in the country as a result of changes and easing the Rouanet Law, which supports cultural activities.

Very significant were the growth rates of Video games and Toys imports in the latter period because of the difficulties of internal development of the production of these products, as compared to international competition, given that internally is still limited the support for technological progress in a international context of intense transformation of the technical basis.

In short, the analysis of Brazilian foreign trade flows of creative tangible and intangible industries shows that the use of this trade to collaborate at the country's economic development process is still at an early stage, but is shows an expansion capability to export to international market niches. In this sense, specific public policies should have the function to stimulate these sales through financial support, regulation and the creation of other institutions that render more flexible the trade flows of the creative chain activities, in order to facilitate the multiplier impact on the economy.

\section{FINAL CONSIDERATIONS: CHALLENGES FOR PUBLIC POLICY}

The recent emergence in Brazil of the awareness about the economic potential and role of creative industry as a driver for income, jobs and value generation, has spread among experts from public and private sectors, as an idea for growth strategy and market diversification, although the stimulus for these activities by public policies date back to 2011, with the creation of the Secretariat of the Creative 
Economy (SEC) and are still in a phase of planning and formulation of institutional goals and others.

The processes that generate these values from the creative production chain are supported and facilitated by a number of institutions recently created by public and private sectors of society and the economy. The role of government in promoting support to the creative economy and regulation of these activities is growing and preponderant today, in order to stimulate the continuity of changes aimed at the development or the search for solutions to income growth and employment resumption in these times of international crisis overcoming. Public policy measures, whether in the form of subsidies, production financing and research, or other forms of official support, bring these activities to the field of government accountability as part of his duties as manager and director of the domestic economy.

Creative activities depend on inputs of both the formal and informal economic sectors and it becomes important to assess how public initiatives to promote these activities in these settings, can shape the way of the creative chain and its development multiplier effects. Much of the workers regarded as representatives of the creative economy in Brazil, are in informal conditions in the labor market, and are not detected in the official estimates and government regulation, while it does not have access to stimulus measures and official support.

Micro-enterprises, associations, clubs and other group activities that occupy most of the cultural institutions as creative agents, also tend to be smaller and less visible in the economy and are less able to interact with the international environment and thus, there are systematic and persistent asymmetries in relation to its domestic and international competitiveness capacity.

Thus, the first challenge of public policies in the country is to obtain reliable and more disaggregated data on these activities, because the national aggregate statistics about cultural flows of inputs and products, do not provide the necessary information on sector and regional specificities. A pragmatic public policy still requires a better knowledge of the agents that support the creative chain (stakeholders), how the creative sector relates to other economic sectors and thus the policy initiative must be specific and not generic.

The government stimulus to creativity is not an optional goal, but it is today a matter of strategy, to guide and provide tools that give opportunity to economic added value creation, in the various sector levels with different skills and experiences. In this sense, development policy not only mean investment in infrastructure (such as sanitation, roads or houses), but also pass through the understanding of the impacts of interventions for potential stimulus of individuals and communities affected by the benefits of cultural, social and environmental projects that are part of the creative chain.

There are challenges to be faced in the country in what refers to these stimuli as: access to finance; formation of a network institutions, agents and intermediaries to operate creative activities; solving the problems of distance that block the activities in remote areas; understanding of popular demands culture and other aspects; possibility of access the international market connections and flows; mapping of creative capital assets and human sites; ensure intellectual property and 
copyright rights; and particularly provide the skills and technical capabilities, business and other for the administration of creative activities.

On this basis it is urgent the articulation and stimulation to develop creative endeavors, which primarily includes education for creative skills and competences, and the creation of a physical and regulatory infrastructure that enables the creation, production, distribution, consumption and export of goods and creative services.

In short, many regions of the world are recognizing the opportunity to promote a more intense growth of the creative chain to support the overall development of the economy. However, the creative chain in Brazil is still emerging as an economic force and there is not enough experience for the development of global models of public action and it is up to each government jurisdiction to develop promotional measures aiming their own local reality, however seamlessly with other spheres and related government areas.

\section{REFERENCES}

Bakhshi, Hasan, Hargreaves, Ian and Mateos-Garcia, Juan. The Manifesto for the Creative Economy, NESTA, London, 2013.

BRAZIL (2012), Creative Economy Secretariat Plan. Guidelines policies and actions, 2011-2014, Ministry of Culture, Brasilia.

CBC (2008), Valuing Culture: Measuring and Understanding Canada's Creative Economy, The Conference Board of Canada Report, Ottawa.

CEC (National Creativity Network) (2013), America's Creative Economy, CEC, Oklahoma.

DCMS (UK Department of Culture, Media and Sport) (1998), Mapping the Creative industries: a toolkit, Creative and Cultural Economy series / 2, London.

FIRJAN (2008), The Creative Industry Chain in Brazil, DECON / FIRJAN, Rio de Janeiro.

FIRJAN (2011), The Creative Industry Chain in Brazil, 2011 FIRJAN, Rio de Janeiro.

FIRJAN (2012), Creative Industries Mapping in Brazil, FIRJAN, Rio de Janeiro.

FUNDAP (2012), Creative Economy, FUNDAP, Sao Paulo.

Furtado, Celso (1981), Small introduction to development: an interdisciplinary approach, Editora Nacional (2nd edition), Sao Paulo.

Greffe (2006), Xavier, Managing Creative Enterprises. Creative industries, UN / World Intellectual Property Orbanization (WIPO), Booklet No. 3, Geneva.

IBGE / PAS (2007, 2009 and 2010), Annual Survey of Services, IBGE, Rio de Janeiro.

IBGE / PNAD (2007, 2009 and 2011), National Survey of Households, IBGE, Rio de Janeiro.

IPEA (2013), Panorama of the creative economy in Brazil, TD N0 1880, Brasilia.

Kon, Anita (2015), The New Political Economy of the Services, Publisher Perspective, Sao Paulo.

Throsby, David (2007), Modelling the Creative / Cultural Industries, Macquarie University, Edinburgh, Scotland.

UN (2010), Creative Economy Report 2010, UNCTAD, New York.

UNCTAD (2008), Creative Economy Report. 2008. The challenge of Assessing the creative Economy towards Informed Policy-making, UN, New York.

UNCTAD (2010), Creative Economy Report 2010, UN / UNCTAD.

UNCTAD (2011), Creative Economy Report. The feasible development option, Creative Economy Report 2010, Geneva.

UNCTAD (2014), Widening Local Development Pathways, Creative Economy Report, 2013 Geneve.

UNCTADstat (2014), United Nations Conference on Trade and Development, Geneva.

UNESCO (2013), United Nations Creative Economy Report 2013, UN, New York. 